\title{
Plasmodium, Saurocytozoon and Haemocystidium parasites (Apicomplexa: Plasmodiidae) from the rock agama, Laudakia caucasia (Sauria: Agamidae), in southern Asia
}

\author{
Sam R. Telford, Jr.
}

The Florida Museum of Natural History, University of Florida, Gainesville, Florida, USA

\begin{abstract}
The rock agama, Laudakia caucasia Eichwald (Agamidae) is host to Plasmodium caucasica sp. n. and Saurocytozoon agamidorum sp. n. in western Pakistan. Plasmodium caucasica is characterized by very large meronts, 11-21 by $8-17 \mu \mathrm{m}$ that produce 32-67 merozoites, which nearly fill the host erythrocyte, and smaller, ovoid to elongate gametocytes, $6-14$ by $2.5-6 \mu \mathrm{m}$, with length by width (LW) $21-55 \mu \mathrm{m}^{2}$, and L/W ratio 1.0-4.0. Host cells are usually mature erythrocytes. In Azerbaijan, $P$. caucasica parasitizes immature erythroid cells. Dimensions of meronts are $10-16$ by $6-12 \mu \mathrm{m}$, and merozoite numbers are $12-44$. Gametocytes are $6-14$ by 3-6 $\mu \mathrm{m}$, with LW $31-56 \mu \mathrm{m}^{2}$, and L/W ratio 1.0-4.0. Saurocytozoon agamidorum sp. n. gametocytes are $6.5-13 \mu \mathrm{m}$ in diameter, with LW 35-79 $\mu \mathrm{m}^{2}$, and L/W ratio 1.0-2.2. They occupy lymphocytes as host cells, which are greatly distorted by gametocyte presence and often show nuclei nearly divided into two portions, one portion at each end of the cell. Haemocystidium grahami (Shortt, 1922), redescribed from material found in L. caucasia from Azerbaijan, has rounded to elongate gametocytes, 8-19.5 by 4-8 $\mu \mathrm{m}$, LW 60.5-102 $\mu \mathrm{m}^{2}$, and L/W ratio 1.0-4.5. The prominent light golden pigment granules often coalesce to nearly cover the surface of the gametocyte. The presence of P. caucasica and S. agamidorum extends the range of the two genera in saurian hosts throughout much of the southern Asia mainland.
\end{abstract}

Keywords: blood parasites, plasmodiids, Plasmodium caucasica sp. n., Saurocytozoon agamidorum sp. n., Haemocystidium grahami, lizards, Pakistan, Azerbaijan

In contrast to hemogregarines, which are the characteristic and most common hemoparasites of snakes (Telford et al. 2012), plasmodiid species of lizards (species of genera Plasmodium Marchiafava et Celli, 1885; Haemocystidium Castellani et Willey, 1904; Saurocytozoon Lainson et Shaw, 1969; Fallisia Lainson, Landau et Shaw, 1974) in most geographic areas greatly exceed hemogregarines in prevalence and diversity. Twelve extensive surveys of lizard communities by the author from North, Middle and South America, Eastern, Southeastern and Southern Asia, and East Africa from 1961-1988 (see Table 1) found plasmodiid infections to be $>4$ times the abundance of hemogregarines, and saurian species to be infected 1.7 times greater, overall.

The only area in which plasmodiids seemed to be absent was southern California. An adequate sample of 116 Sceloporus occidentalis Baird et Girard were negative for Plasmodium mexicanum Thompson et Huff, 1944. In northern California, the sample of lizards examined was less than one-third total sample from southern California, yet the prevalence of $P$. mexicanum was $16 \%$ of $288 \mathrm{~S}$. occidentalis, the only saurian species examined. Hemogregarines were present in the southern California community, but were not found in the northern California sample, despite their recorded presence in the study areas by other workers. The only other areas in which hemogregarines were found in greater prevalence than plasmodiids were Venezuela and Pakistan, but the latter were present in both.

Plasmodiid parasites of the genera Plasmodium, Fallisia, and Saurocytozoon have not been described from lizards of mainland southern Asia, although several species of Haemocystidium are known from geckoes and agamids. The rock agama, Laudakia caucasia Eichwald (Sauria: Agamidae) is host to undescribed species of Plasmodium and Saurocytozoon in western Pakistan, and to Plasmodium and Haemocystidium grahami Shortt, 1922 in Azerbaijan. Their description below closes a gap in our knowledge of their distribution.

\section{MATERIALS AND METHODS}

A series of Laudakia caucasia were collected by the author in western Baluchistan in 1975-1976. Initial screening recorded the presence of hemogregarines and hemococcidia, and indicated a possible Haemocystidium infection in three lizards. After 35 years, the slides were re-examined while cataloging them and Plasmodium infections were found in several lizards, and Saurocytozoon in one. Several slides from Azerbaijan from the same host species, sent to the author in the early 1990's, were found to have Plasmodium and Haemocystidium infections present. 
Table 1. Relative abundance of plasmodiid (PL) and haemogregarine (HG) infections in 12 lizard communities of North, Middle, and South America, Eastern, Southeastern and Southern Asia, and East Africa.

\begin{tabular}{|c|c|c|c|c|c|c|c|c|c|c|}
\hline Area & $\begin{array}{c}\mathrm{N} \text { lizards } \\
\text { exam }\end{array}$ & $\begin{array}{l}\text { N spp. } \\
\text { Exam. }\end{array}$ & $\begin{array}{l}\mathrm{N} \text { infect. } \\
\text { found }\end{array}$ & N PL inf. & N PL spp.* & $\% \mathrm{~N}$ inf. & $\begin{array}{l}\text { N PL host } \\
\text { spp. }\end{array}$ & N. HG. inf. & $\begin{array}{l}\text { No. HG } \\
\text { host spp. }\end{array}$ & $\% \mathrm{~N}$ Inf. \\
\hline Florida & 2728 & 20 & 200 & 195 & $1(1)$ & 97,5 & 3 & 5 & 3 & 2.5 \\
\hline SW USA & 446 & 34 & 71 & 60 & 1 & 84.5 & 3 & 11 & 6 & 15.5 \\
\hline Southern California & 939 & 27 & 0 & - & - & 0 & 0 & 6 & 2 & 100 \\
\hline Northern California & 288 & 3 & 45 & 45 & 1 & 100 & 1 & 0 & 0 & - \\
\hline Middle America & 612 & 41 & 123 & 93 & $8(1)$ & 75.6 & 20 & 30 & 6 & 24.4 \\
\hline Panama & 2036 & 35 & 752 & 690 & $21(2)$ & 91.8 & 13 & 62 & 9 & 8.2 \\
\hline Venezuela & 828 & 20 & 198 & 91 & $15(3)$ & 46 & 7 & 107 & 5 & 54 \\
\hline Caribbean & 778 & 50 & 161 & 131 & $7(2)$ & 81.4 & 20 & 30 & 6 & 18.6 \\
\hline Japan & 2138 & 9 & 16 & 16 & $2(1)$ & 100 & 3 & 0 & 0 & - \\
\hline SE Asia & 919 & 13 & 108 & 82 & $8(1)$ & 75.9 & 13 & 26 & 9 & 75 \\
\hline Pakistan & 855 & 40 & 72 & 18 & 6 & 25 & 6 & 54 & 9 & 75 \\
\hline \multirow[t]{2}{*}{ Tanzania } & 1024 & 42 & 207 & 176 & 16 & 85 & 17 & 31 & 7 & 15 \\
\hline & 13591 & 334 & 1959 & 1597 & $86(11)$ & 81.5 & 106 & 362 & 62 & 18.5 \\
\hline
\end{tabular}

*(n) indicates number of species also occurring in other geographic areas.

After capture by noose, lizards were maintained for short periods of time on a diet of small arthropods. Blood samples, obtained by toe clipping and placed upon slides, were fixed with absolute methanol, then stained for $1 \mathrm{hr}$ by Giemsa in a $1: 10$ dilution at $\mathrm{pH}$ 7.0. Slides were screened at $400 \times$, studied, measured, and photographed at $1000 \times$ under oil immersion. Taxonomic characters were those used by Telford (1988). All measurements, obtained by a calibrated ocular micrometer, are in micrometres $(\mu \mathrm{m})$ with means and SD followed by ranges in parentheses, or in the case of LW (length $\times$ maximum width) values, $\mu \mathrm{m}^{2}$. Comparisons were done by one-way ANOVA on transformed data $(\log \mathrm{x}+1)$ with significance $\mathrm{P}<0.05$. Differences noted below (smaller, larger, greater, less, etc.) were statistically significant; the term 'similar to' indicates that significant differences were not present. Pigment presence was determined by refraction under polarized light in all parasites measured.

\section{RESULTS}

\section{Plasmodium caucasica sp. n.}

Figs. 1-28

Asexual stages: Uninucleate parasites rounded to ovoid, $4-6$ by $3.5-4$, pigmented, with prominent central vacuole usually present. Nuclear division evident at 5 by 3,4 nuclei present commonly at $5-7$ by $3.5-4.5$, and 8 nuclei at 5 by 4 , but size varies at onset of merogony, $3-4$ nuclei observed at $16-18$ by $3-4$. Mature meronts (Figs. $1-6) 16.5 \pm 2.2$ by $12.7 \pm 2.1$ (11-21 by $8-17$, $\mathrm{n}=25)$, and contain $47.2 \pm 8.9$ (32-67) tightly packed merozoites. Host cells erythrocytes, almost all distorted $(92 \%)$, seldom with distorted or displaced nuclei (16\%). Meronts usually fill host cells, but immature meronts may lie lateral $(20 \%)$, lateropolar $(16 \%)$, or polar $(4 \%)$ to the erythrocyte nucleus, when not filling the host cell. Host erythrocytes broader in width but not significantly enlarged in LW compared to uninfected erythrocytes, their nuclei not different in dimensions. Pigment granules small, dark, not clustered as mass.

Gametocytes: Immature gametocytes ovoid to elongate. Mature gametocytes (Figs. 7-12) typically elongate
( $92 \%$ ), occasionally ovoid, $9.9 \pm 2.1$ by $4.0 \pm 0.9$ (6-14 by $2.5-6, \mathrm{n}=25)$, LW $39.4 \pm 10.6 \mu \mathrm{m}^{2}(21-55), \mathrm{L} / \mathrm{W} 2.58 \pm$ 0.78 (1-4). Macrogametocytes (Figs. 7-9) $9.9 \pm 3.0$ by $4.3 \pm 0.5(6-15$ by $3-6, \mathrm{n}=18)$, with LW $36.6 \pm 5.8 \mu \mathrm{m}^{2}$ (24.5-50) and L/W $2.33 \pm 0.41$ (1.5-3.3), and microgametocytes (Figs. 10-12) $8.9 \pm 0.8$ by $4.5 \pm 0.5$ (7-10 by 4-6 $\mathrm{n}=25)$, LW $40.1 \pm 4.6 \mu \mathrm{m}^{2}(34-51, \mathrm{n}=25)$, and L/W $1.98 \pm 0.32(1.3-2.5)$. Gametocyte size relative to infected erythrocyte nucleus size 1.63 (1.14-2.16), and to normal erythrocyte nuclei 1.76 (1.12-2.34). Small vacuoles present rarely (6\%). Gametocytes usually lateral (46\%) or lateropolar (50\%) to host cell nucleus, rarely polar (4\%).

All parasitizite erythrocytes, always distort host cell and usually displace its nucleus (81\%), but never distort nucleus. Length of host erythrocytes lower, but their width greater that of uninfected cells, with no effect upon LW. Infected erythrocyte nuclei shorter in length but greater in width and LW than nuclei of uninfected cells. Gametocytes sexually dimorphic in size, macrogametocytes longer than microgametocytes with greater LW; width and $\mathrm{L} / \mathrm{W}$ ratio did not differ. Nuclei of macrogametocytes $2.5-5$ by $1-2$, elongate or occasionally oval; chromatin diffuse in microgametocytes and nucleoli rarely visible. Pigment granules small, not clumped, dark.

Type and only host: Laudakia caucasia Eichwald(Sauria: Agamidae).

Type locality: 9 km East of Ziarat, Sibi District, Baluchistan Province, Pakistan $\left(30^{\circ} 22^{\prime} \mathrm{N}, 67^{\circ} 44^{\prime} \mathrm{W}\right)$.

Additional localities: Azerbaijan, Absherai Peninsula and Gobustan, Boyuk Dash area (but see Remarks).

Site of infection: Erythrocytes.

Prevalence: Seven of $39(18 \%)$ in Pakistan, by examination of blood films.

Material deposited: Hapantotypes: U.S. National Parasite Collection, Beltsville, Maryland (USNPC 106057, 106058), parahapantotypes deposited with the Telford collection at the Manter Museum of Parasitology, University of Nebraska State Museum, Lincoln, Nebraska. Symbiotype 


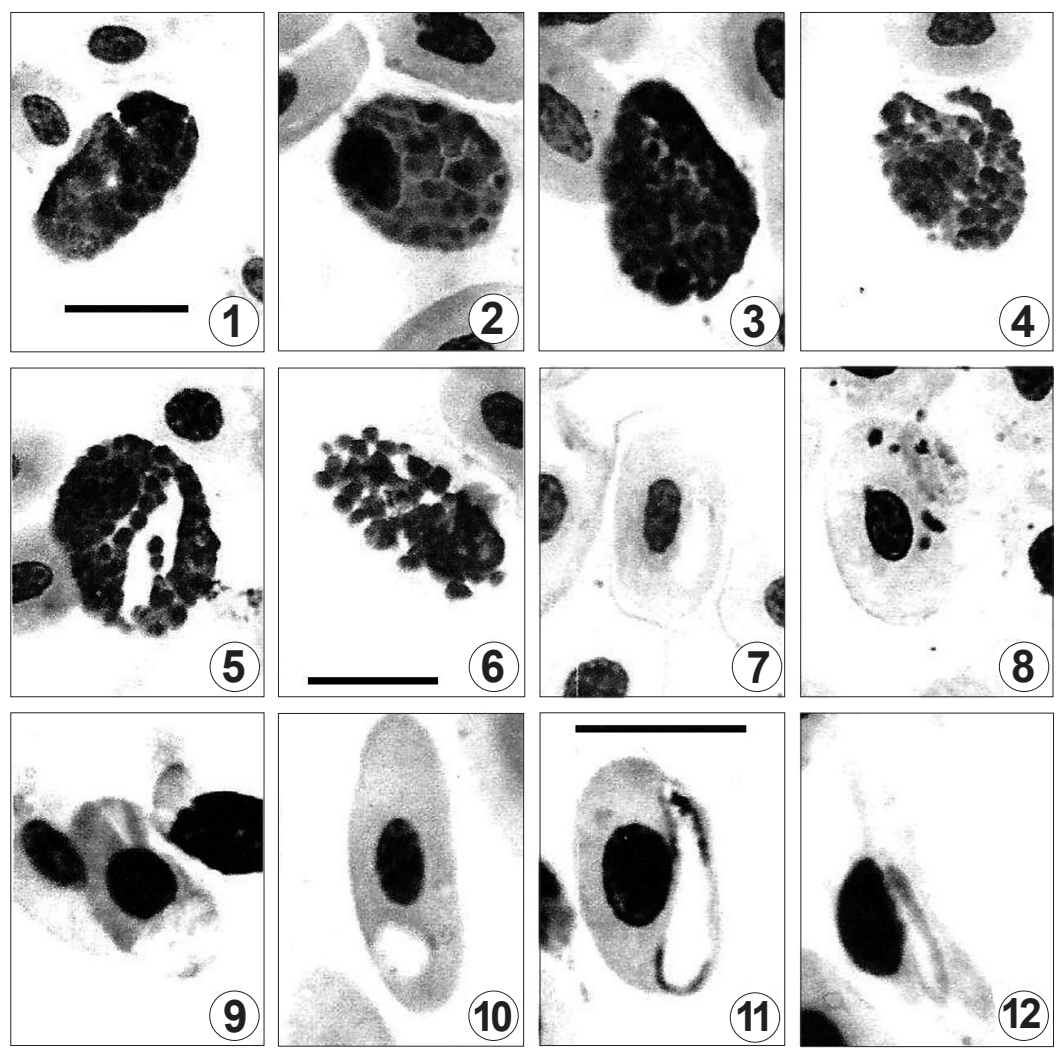

Figs. 1-12. Plasmodium caucasica sp. n. from Laudakia caucasia, Pakistan. Figs. 1-6. Erythrocytic meronts. Figs. 7-9. Macrogametocytes. Figs. 10-12. Microgametocytes. Scale bars $=10 \mu \mathrm{m}$. Scale bars in Figs. 1, 6 represent dimensions in Figs. 1-10. Scale bar in Fig. 11 also represents dimensions in Fig. 12.

deposited, Florida Museum of Natural History, University of Florida, Gainesville, Florida (UF 70321).

E ty mology: The specific name reflects that of the host.

Remarks. Laudakia caucasia from Azerbaijan were infected by a Plasmodium species, which is probably P. caucasica (Figs. 13-28). Meronts (Figs. 13-20) were $13.5 \pm 1.7$ by $8.7 \pm 1.5 \mu \mathrm{m}(10-16$ by $6-12, \mathrm{n}=25)$, with $26.4 \pm 7.3(12-44)$ nuclei present in meronts. Gametocytes (Figs. $21-28)$ were $10.1 \pm 1.9$ by $4.2 \pm 0.8 \mu \mathrm{m}(6-14$ by $3-6, \mathrm{n}=25)$, LW $41.5 \pm 7.4 \mu \mathrm{m}^{2}(31-56)$, and L/W $2.55 \pm 0.86(1.0-4.0)$, dimensions and appearance closely similar to gametocytes from the Pakistani hosts. The smaller meronts, with fewer nuclei, parasitized immature erythroid cells, erythroblasts $(76 \%)$ or proerythrocytes (24\%); none were seen in erythrocytes, in comparison to the meronts from Pakistani hosts, which occupied only erythrocytes.

Another infection in S. caucasica from Pakistan was apparently comprised primarily by immature meronts, 12-23 by $4-12 \mu \mathrm{m}, 8-32$ merozoites, which also occupied erythrocytes only. The difference in host cell or meront maturity may have contributed to the smaller size of meronts and fewer merozoites in the sample from Azerbaijan. Plasmodium caucasica is unique among saurian malarial parasites in the disproportionate size of meronts to gametocytes, the latter $21-55 \mu^{2}$ in size, in comparison to the much larger meronts, averaging $212 \mu \mathrm{m}^{2}$, which usually fill the host cell.

\section{Saurocytozoon agamidorum $\mathrm{sp} . \mathrm{n}$.}

Figs. 29-36

Gametocytes: $8.2 \pm 1.7$ by $6.2 \pm 0.8(6.5-13.0$ by $5-8$, $\mathrm{n}=25)$, LW $56.3 \pm 12.5 \mu \mathrm{m}^{2}(35-78), \mathrm{L} / \mathrm{W}$ ratio $1.34 \pm$ 0.28 (1.00-2.17). Macrogametocytes (Figs. 29-34) $7.8 \pm$ 1.7 by $6.1 \pm 0.9(6.5-13, \mathrm{n}=14)$, LW $47.9 \pm 13.8 \mu \mathrm{m}^{2}$ (35-78), L/W ratio $1.30 \pm 0.29$ (1.00-2.17). Microgametocytes (Figs. 35,36$), 8.8 \pm 1.7$ by $6.4 \pm 0.7$ (7-12 by $5.5-8, \mathrm{n}=11)$, LW $56.3 \pm 125 \mu \mathrm{m}^{2}(42-78), \mathrm{L} / \mathrm{W}$ ratio $1.38 \pm 0.28(1.00-1.85)$. Unpigmented. A single vacuole sometimes present in gametocytes (Fig. 34). Host cells lymphocytes, greatly distorted by parasite presence, sometimes with a portion of the nucleus in each end of the elongated cell, connected by a narrow band of chromatin (Figs. 35, 36).

Type and only host: Laudakia caucasia Eichwald (Sauria: Agamidae).

Type locality: 9 km East of Ziarat, Sibi District, Baluchistan Province, Pakistan $\left(30^{\circ} 22^{\prime} \mathrm{N}, 67^{\circ} 44^{\prime} \mathrm{W}\right)$.

Site of infection: Lymphocytes.

Prevalence: One of 39 (3\%).

Material deposited: Hapantotype: U.S. National Para- 

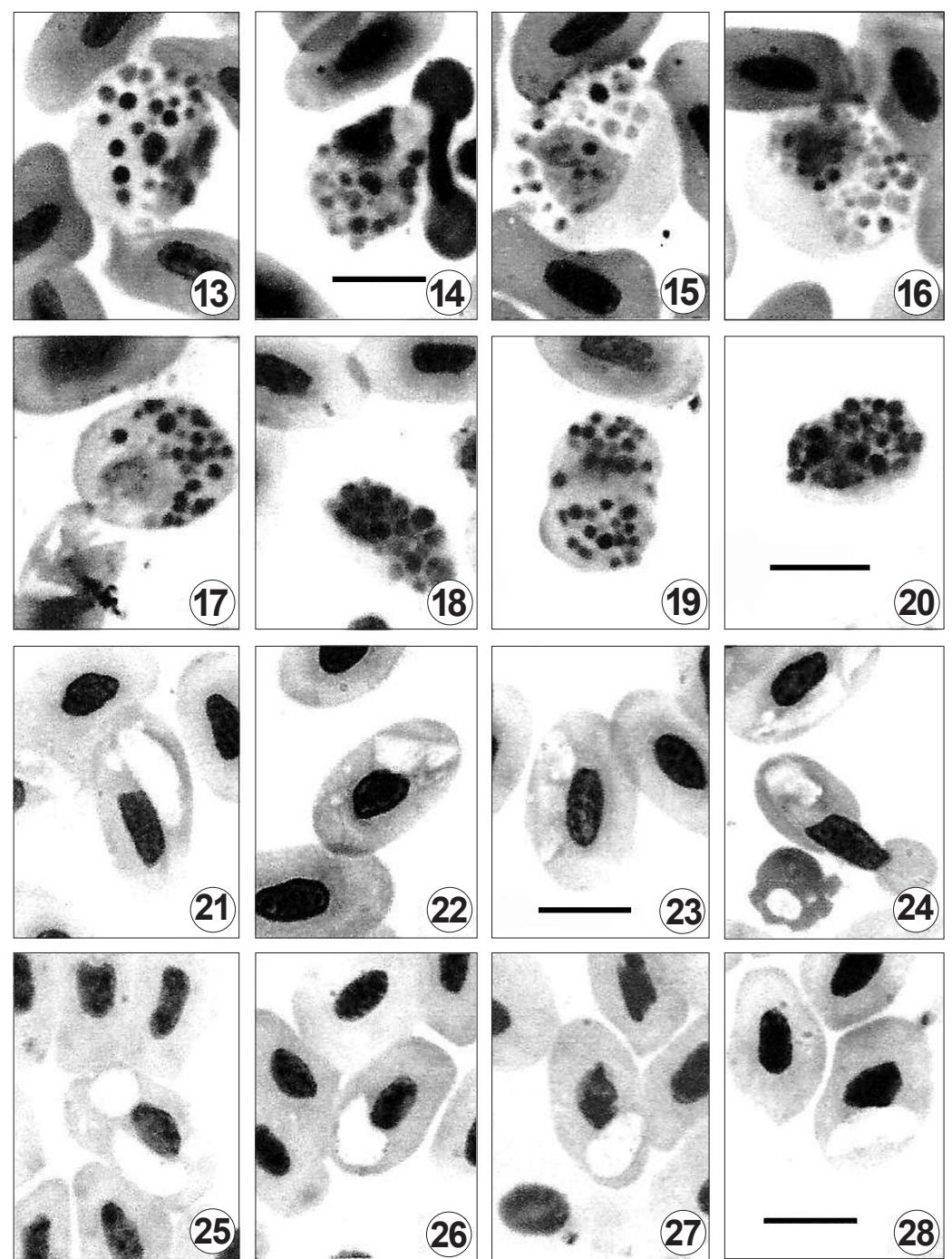

Figs. 13-28. Plasmodium caucasica sp. n. from Laudakia caucasia, Azerbaijan. Figs. 13-20. Meronts in immature erythroid cells. Figs. 21-24. Macrogametocytes. Figs. 25-28. Microgametocytes. Scale bars $=10 \mu \mathrm{m}$. Scale bars in Figs. 14, $20,23,28$ represent dimensions in all figures of the plate.

site Collection, Beltsville, Maryland (USNPC 106059); symbiotype deposited, Florida Museum of Natural History, University of Florida, Gainesville, Florida (UF 70302).

Et y m ology: The specific name reflects the host family.

Remarks. Two Saurocytozoon species have been described: Saurocytozoon tupinambi Lainson et Shaw, 1969 from teiid lizards of Brazil and Venezuela, which parasitizes lymphocytes and occasionally immature erythroid cells, with dimensions $13-17$ by $10-16 \mu \mathrm{m}$, LW 90-206 $\mu^{2}$, and L/W ratio 1.1-1.9, and Saurocytozoon mabuyi Lainson, Landau et Shaw, 1974, which parasitizes lymphocytes and monocytes of the skink Mabuya mabouya (Lacépède) in Brazil, with dimensions 11 by $8 \mu \mathrm{m}$ (Lainson and Shaw 1969, Lainson et al. 1974).

Telford (1983) reported Saurocytozoon parasites in lymphocytes only of Mabuya multifasciata (Kuhl) in Thailand and Singapore. The dimensions of 7-16 by
6-11 $\mu \mathrm{m}$, LW 49-160 $\mu \mathrm{m}^{2}$, and L/W ratio of 1.0-2.2, and their appearance did not distinguish them from $S$. mabuyi, and it was considered to be that species.

Saurocytozoon agamidorum is similar to both other species in dimensions, $6.5-13$ by $5-8 \mu \mathrm{m}$, LW $35-78 \mu \mathrm{m}^{2}$, and $\mathrm{L} / \mathrm{W}$ ratio $1.00-2.17$. However, it produces more severe effects upon the morphology of the host lymphocytes and their nuclei, often stretching the nucleus out, resembling two halves of the nucleus connected by a narrow belt of chromatin. Other leucocytes of the host lizard, polymorphonuclear leucocytes or neutrophils (Figs. 37-40), contained inclusions that strongly resembled plasmodiid meronts in various stages of nuclear division. Without further study it is impossible to definitely relate these apparent asexual stages to $S$. agamidorum, but their appearance in the only lizard host to $S$. agamidorum gametocytes, in an adequate series from the type locality, is suggestive. 

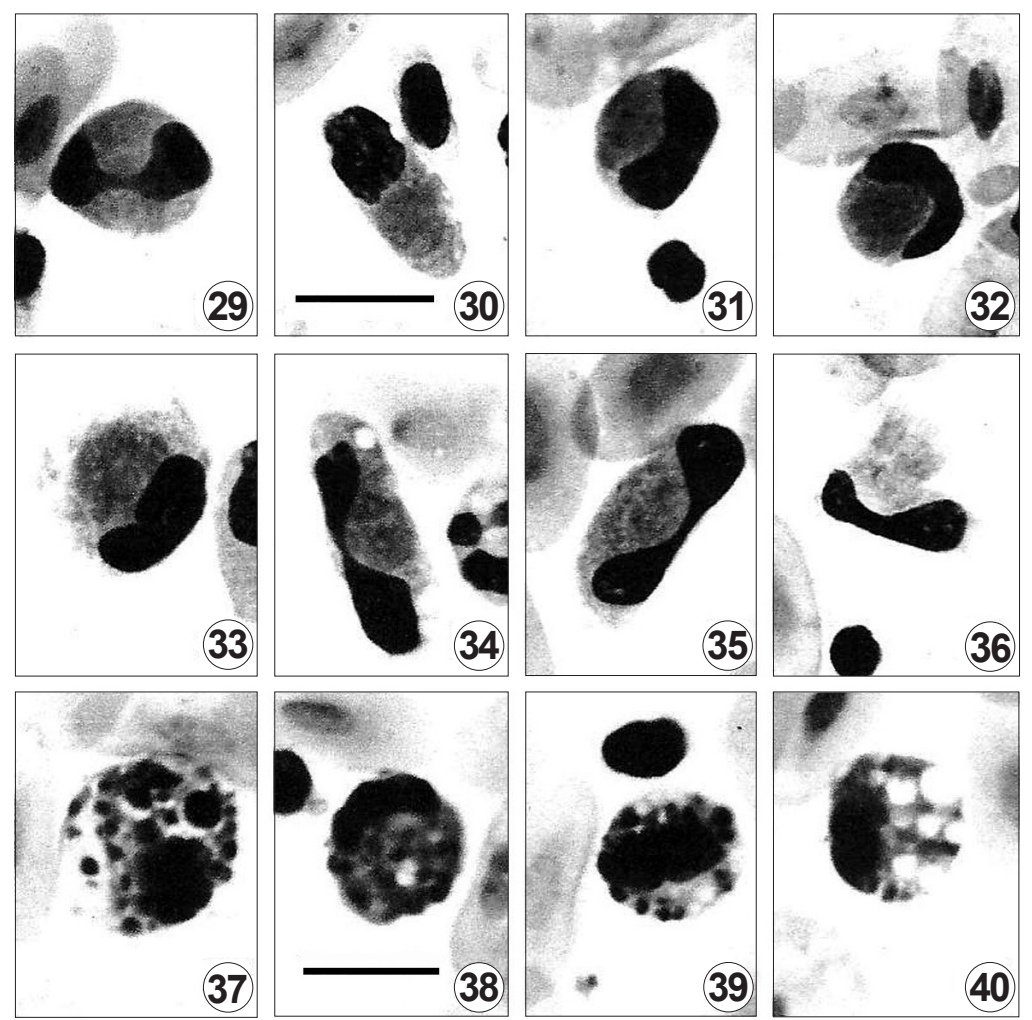

Figs. 29-40. Saurocytozoon agamidorum sp. n. in lymphocytes from Laudakia caucasia, Pakistan. Figs. 29-34. Macrogametocytes. Figs. 35, 36. Microgametocytes. Figs. 37-40. Possible meronts. Host cells polymorphonuclear leucocytes or neutrophils. Scale bars $=10 \mu \mathrm{m}$. Scale bars in Figs. 30, 38 represent dimensions in all figures of the plate.

\section{Redescription of Haemocystidium grahami}

(Shortt, 1922) Telford, 1996

Figs. 41-48

Gametocytes: $12.8 \pm 2.6$ by $6.1 \pm 0.9(8-19.5$ by $4-8$, $\mathrm{n}=25)$, LW $76.8 \pm 10.8 \mu \mathrm{m}^{2}(60.5-102), \mathrm{L} / \mathrm{W}$ ratio 2.18 $\pm 0.78(1.0-4.5)$. Dimensions similar between sexes: macrogametocytes (Figs. 41-45) $12.1 \pm 2.0$ by $6.0 \pm 1.0$ (8-14.5 by $5.5-8, \mathrm{n}=12$ ), LW $75.6 \pm 8.5 \mu \mathrm{m}^{2}(60.5-84)$, $\mathrm{L} / \mathrm{W}$ ratio $1.97 \pm 0.48(1.00-2.64)$; microgametocytes (Figs. 46-48) $13.4 \pm 3.1$ by $6.0 \pm 1.0(10-19.5$ by $4-7.5$, $\mathrm{n}=13)$, LW $77.8 \pm 12.9 \mu \mathrm{m}^{2}(63-102), \mathrm{L} / \mathrm{W}$ ratio $2.38 \pm$ $0.96(1.33-4.50)$. Both sexes with prominent light golden pigment granules, variably located in cytoplasm, which in some gametocytes form a large, shapeless mass that may nearly cover the gametocyte (Figs. 47-48).

Merogony: Unknown.

Ty p e host: Laudakia nupta (De Filippi) (Sauria: Agamidae) Other hosts: Laudakia caucasia; L. erythrogaster (Nikolsky), L. lehmani (Nikolsky) (see Ovezmukhammedov 1987).

Type locality: Not stated, but range of host described as 'west and northwest Persia' (Shortt, 1922).

Additional localities: Azerbaijan, Absherai Peninsula and Gobustan, Boyuk Dash area (Alivyev 2000).

Site of infection: Erythrocytes.

Prevalence: Unknown.

Material deposited: Neohapantotype: U.S. National Parasite Collection, Beltsville, Maryland (USNPC 106060); symbiotype not deposited. Vouchers deposited with the Telford collection at the Manter Museum of Parasitology, University of Nebraska State Museum, Lincoln, Nebraska.

Etymology: The specific name apparently refers to a colleague of its author.

Remarks. Reports of H. grahami in the literature from agamids in Turkmenistan and Uzbekistan (cited by Ovezmukhammedov 1987) apparently represent $H$. papernae Telford, 1996 because of the halteridial gametocytes (Telford 1996, 2009). Telford (2009) attempted to obtain more precise dimensions for the two mature gametocytes of H. grahami shown by Shortt (1922), by calculating host uninfected erythrocyte dimensions from L. nupta of Pakistan and comparing them with those present in Shortt's figures, which resulted in dimensions greater than those stated by Shortt, 22.9 by $15.4 \mu \mathrm{m}$ and 18.7 by $14.7 \mu \mathrm{m}$, $v \mathrm{~s}$ ' 12 to 14 microns'. Since Shortt's data are so limited, these calculated dimensions clearly are not reliable. All other described Haemocystidium species have pigment distributed as compact granules of varying sizes but not in large masses nearly covering the gametocyte surface. Shortt (1922), however, described the appearance of pigment present in gametocytes in pulmonary blood as "parasites infecting blood cells in the lungs seemed to produce enormous quantities of pigment in abnormally large grains, the pigment frequently almost obliterating the outlines of 

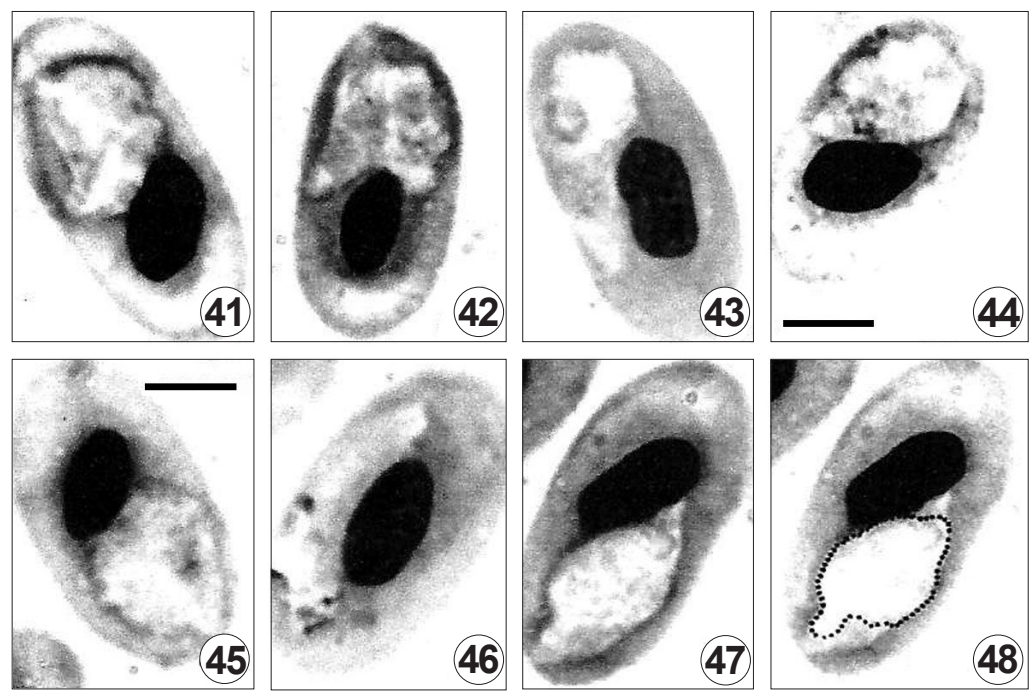

Figs. 41-48. Haemocystidium grahami (Shortt, 1922) from Laudakia caucasia, Azerbaijan. Figs. 41-45. Macrogametocytes. Figs. 46-48. Microgametocytes. Extent of pigment mass in Fig. 47 outlined in Fig. 48. Scale bars $=10 \mu \mathrm{m}$. Scale bars in Figs. 44, 45 represent dimensions in all figures of the plate.

the infected cell." He speculated that this difference in extent of pigment might be due to the effects of smearing the blood on slides in comparison to sectioning the host cells within the blood vessels. The common presence of huge amounts of light golden pigment nearly covering the surface of the gametocytes in infected $S$. caucasia from Azerbaijan, described here (Figs. 47-48), strengthens their identification as H. grahami.

\section{DISCUSSION}

The distribution of described saurian plasmodiid species in mainland Asia from the Indian subcontinent to the eastern Mediterranean suggested that Haemocystidium species alone represented the family there. The description here of Plasmodium caucasica and Saurocytozoon agamidorum, however, demonstrates that this apparent absence lacks zoogeographic significance, and is instead a result of inadequate sampling of lizard populations throughout southern Asia and Mediterranean Europe. Plasmodium, Saurocytozoon and Fallisia all are present in southeast Asia (Telford 2009). In East Asia, at least one species each of Plasmodium ( $P$. sasai Telford et
Ball, 1969) and Fallisia (F. kantoensis Telford, 2009) are known from Japan. Both Plasmodium (P. clelandi Manawadu, 1972) and Haemocystidium (H. simondi Castellani et Willey, 1904) occur in Ceylon, and the latter species is recorded from Indian geckoes (Shortt 1962). Seven species of Haemocystidium have been described from India to the Mediterranean (Telford 2009), and one species (H. tarentolae (Parrot) 1927) occurs in southern Europe as well as northern Africa. A Plasmodium species was reported to parasitize Spanish lizards, probably lacertids, (Alvarez Calvo and Milan Jimenez 1974) but its presence and generic identity have not been verified by further published research. Its morphological characters remain unknown. It is unlikely that plasmodiid diversity in southern Asia, particularly in xeric areas, will be found similar to that present in the New World, African, and southeast Asian tropics, but the genera of plasmodiids that infect saurians are certainly cosmopolitan in their distribution.

Acknowledgments. The author thanks Sam R. Telford, III for his assistance in collecting the host lizards in Western Baluchistan, and Mehdi A. Aliyev for providing the samples from Azerbaijan.

\section{REFERENCES}

Aliyev M.A. 2000: [Haemoparasites of the reptiles of Absheron Peninsula and Gobustan]. Azerbaijan Akad. Nauk. 28 pp. (In Russian.)

Alvarez Calvo J., Milan Jimenez F. 1974: On some haemoparasites from Spanish reptiles. Proc. $3^{\text {rd }}$ International Congress Parasitol, Munich, 1974, 1: abstracts of papers p. 19

LAinson R., LAndau I, Shaw J.J. 1974: Observations on nonpigmented haemosporidia of Brazilian lizards, including a new species of Saurocytozoon in Mabuya mabouya (Scincidae). Parasitology 69: 215-233.
Lainson R., Shaw J.J. 1969: A new haemosporidian of lizards, Saurocytozoon tupinambi gen. nov., sp. nov. in Tupinambis nigropunctatus (Teiidae). Parasitology 59: 159-162.

Ovezmukhammedov A. 1987: [Protistofauna of reptiles.] A. Berdiev (Ed.) Ilim, Turkman S.S.R., Ashkabad, 373 pp. (In Russian.)

Short H.E. 1922: Review of the position of the genus Haemocystidium (Castellani and Willey, 1904), with a description of two new species. Ind. J. Med. Res. 9: 814-826. 
ShortT H.E. 1962: Exo-erythrocytic schizont of Haemoproteus, parasite of the gecko Hemidactylus sp. in the liver. Trans. Roy. Soc. Trop. Med. Hyg. 56: 3.

TELFORD S.R., JR. 1983: Saurocytozoon parasites (Haemosporidia: Plasmodiidae) from southeast Asian skinks. J. Parasitol. 69: 1141-1145.

TElford S.R., JR. 1988: A contribution to the systematics of the reptilian malaria parasites, family Plasmodiidae (Apicomplexa: Haemospororina). Bull. Florida State Mus., Biol. Sci. 34: 65-96.

Received 26 November 2012
TElford S.R., JR. 1996: Two new species of Haemocystidium Castellani and Willey (Apicomplexa: Plasmodiidae) from Pakistani lizards, and the support their meronts provide for the validity of the genus. Syst. Parasitol. 34: 197-214.

Telford S.R., JR. 2009: Hemoparasites of the Reptilia. CRC Press, Taylor and Francis Group, Boca Raton, Florida, 376 pp.

Telford S.R., Jr., Moler P.E., Butler J.F. 2012. Four additional Hepatozoon species (Apicomplexa: Hepatozoidae) from north Florida ratsnakes, genus Pantherophis. Folia Parasitol. 59: 167-172.

Accepted 4 February 2013 